November 2004

\title{
Dynamic mechanical (brush) allodynia in cluster headache
}

\author{
Avi Ashkenazi \\ Thomas Jefferson University \\ William B. Young \\ Thomas Jefferson University
}

Follow this and additional works at: https://jdc.jefferson.edu/neurologyfp

Part of the Neurology Commons

Let us know how access to this document benefits you

\section{Recommended Citation}

Ashkenazi, Avi and Young, William B., "Dynamic mechanical (brush) allodynia in cluster headache" (2004). Department of Neurology Faculty Papers. Paper 7.

https://jdc.jefferson.edu/neurologyfp/7

This Article is brought to you for free and open access by the Jefferson Digital Commons. The Jefferson Digital Commons is a service of Thomas Jefferson University's Center for Teaching and Learning (CTL). The Commons is a showcase for Jefferson books and journals, peer-reviewed scholarly publications, unique historical collections from the University archives, and teaching tools. The Jefferson Digital Commons allows researchers and interested readers anywhere in the world to learn about and keep up to date with Jefferson scholarship. This article has been accepted for inclusion in Department of Neurology Faculty Papers by an authorized administrator of the Jefferson Digital Commons. For more information, please contact: JeffersonDigitalCommons@jefferson.edu. 


\section{Dynamic Mechanical (Brush) Allodynia in Cluster Headache}

\section{Background}

Cutaneous allodynia is the perception of pain when a non-noxious stimulus is applied to normal skin. ${ }^{1}$ It has been described in patients with migraine. ${ }^{2-4}$ Cutaneous allodynia is caused by sensitization of central nervous system neurons that receive convergent sensory input from both skin and intracranial structures. ${ }^{5}$ This phenomenon has not been previously described in patients with cluster headache. Although migraine and cluster headache $(\mathrm{CH})$ may share some clinical features, the pathogenesis of these two primary headaches is different. ${ }^{6}$

The aim of this study was to examine the occurrence of dynamic mechanical (brush) allodynia (BA) in patients with $\mathrm{CH}$.

\section{Patients and Methods}

We examined adult patients with episodic or chronic cluster headache $(\mathrm{CH})$. Demographic data and the characteristics of each patient's $\mathrm{CH}$ (type of $\mathrm{CH}$, phase in the disease, disease duration and disease severity) were obtained through a standardized questionnaire. Allodynia testing was performed by repetitively applying a $4 x 4$-inch gauze pad at a rate of $2 / \mathrm{sec}$ to six skin areas bilaterally, in the trigeminal and cervical distributions (frontal $\left(\mathrm{V}_{1}\right)$, maxillary $\left(\mathrm{V}_{2}\right)$, mandibular $\left(\mathrm{V}_{3}\right)$, posterior neck $\left(\mathrm{C}_{2}, \mathrm{C}_{3}\right)$, shoulder $\left(\mathrm{C}_{5}\right)$ and inner forearm $\left.\left(\mathrm{C}_{8}\right)\right)$. For patients in acute attack, allodynia testing was performed before treatment and 10 and 20 minutes thereafter. The patients were asked to quantify the degree of allodynia on a $100 \mathrm{~mm}$ visual analog scale (VAS). They 
were also asked to report on headache at the time of testing and to rate it on an 11-point verbal scale. The relations between the location and severity of headache and allodynia were assessed.

\section{Results}

Ten patients were included in the study. All were male. Their mean age was 39.3 years (range: 26-51). Seven patients had episodic $\mathrm{CH}(\mathrm{ECH})$ and three had chronic $\mathrm{CH}(\mathrm{CCH})$. Two patients were in acute attack when tested (both had $\mathrm{ECH}$ ). Five patients were in cluster period but not in acute attack. The three $\mathrm{CCH}$ patients were not in acute attack. Disease duration ranged from 18 months to 38 years. One patient (who had ECH) also suffered from migraine with aura. Eight patients were on headache preventive medications. Seven of them were on monotherapy (four on

verapamil, two on lithium and one on valproic acid) and one was on polytherapy (verapamil and valproic acid).

In total, four of the ten patients $(40 \%)$ had brush allodynia, two of the seven with episodic $\mathrm{CH}(28.6 \%)$ and two of the three with chronic $\mathrm{CH}(66.7 \%)$ (Table 1). Of the two patients in acute attack (both had episodic $\mathrm{CH}$ ), one had BA, which was ipsilateral to the pain. The allodynia decreased 20 minutes after treatment with oxygen (average allodynia score per site: before treatment -16.66 , after treatment -7.16$)$. Pain score also decreased after treatment, from 8 to 3 (on an 11-point verbal scale). The other patient in acute attack had no allodynia. Of the five patients in cluster period but not in acute attack, one (20\%) had BA. Two of the three (66\%) patients with chronic $\mathrm{CH}$ were found to have $\mathrm{BA}$.

We found a trend for allodynia to occur in patients with longer disease duration (median disease duration - 22 years in patients with allodynia vs. 12 years in patients without allodynia- 
Table 2). The difference, however, was not statistically significant, possibly due to the small number of patients.

\section{Comments}

This is the first report on the occurrence of cutaneous allodynia in cluster headache patients. Our results show that cutaneous allodynia may occur not only in migraine but also in other primary headaches.

Allodynia in migraine may be related to sensitization of neurons in the trigeminal nucleus caudalis (TNC) triggered by trigeminal firing. ${ }^{2,5}$ The trigeminovascular system is activated in both migraine and cluster headache. ${ }^{7}$ This provides a theoretical basis for the assumption that neurons in the trigeminovascular system are sensitized in patients with cluster headache, leading to cutaneous allodynia, as well as to head pain. The exact location and type of neurons or receptors (or both) that are sensitized in $\mathrm{CH}$ patients, leading to cutaneous allodynia, is currently unknown. The results of allodynia testing in this study may have been affected by the preventive medications that the majority of patients were on. However, the exact effect of preventive medications on the occurrence of cutaneous allodynia in $\mathrm{CH}$, as well as in migraine, is still to be determined.

In this study there was a trend for allodynia to be more prevalent in patients with $\mathrm{CCH}$ $(2 / 3,66.6 \%)$ as opposed to $\mathrm{ECH}(2 / 728.6 \%)$. When correlating disease duration with the occurrence of allodynia, we found that in patients with allodynia median disease duration was longer than in patients without allodynia (22 vs. 12 years). Since patients with $\mathrm{CCH}$ have in average longer disease duration that those with $\mathrm{ECH}$, these two results (Tables 1 and 2) are consistent. The allodynia in cluster headache may therefore result from a long-lasting time- 
dependent process of neuronal or receptor sensitization. This has been suggested in a model of spinothalamic tract neuronal sensitization after the injection of capsaicin. ${ }^{1}$ Alternatively, the development of allodynia may contribute to the transition from $\mathrm{ECH}$ to $\mathrm{CCH}$ or both processes may share a common cause.

In summary, in this study we show that sensitization of sensory neurons may occur in cluster headache and is not specific to migraine. 


\section{REFERENCES}

1. Willis WD. Role of neurotransmitters in sensitization of pain responses. Ann NY Acad Sci 2001;933:142-156.

2. Burstein R, Yarnitsky D, Goor-Aryeh I, Ransil BJ, Bajwa ZH. An association between migraine and cutaneous allodynia. Ann Neurol 2000;47:614-624.

3. Burstein R, Cutrer MF, Yarnitsky D. The development of cutaneous allodynia during a migraine attack clinical evidence for the sequential recruitment of spinal and supraspinal nociceptive neurons in migraine. Brain 2000;123 ( Pt 8):1703-1709.

4. Ashkenazi A, Young WB. The effects of occipital nerve block on brush allodynia and pain in migraine. Headache 2003;43(5):543 (Abstract).

5. Burstein R, Yamamura H, Malick A, Strassman AM. Chemical stimulation of the intracranial dura induces enhanced responses to facial stimulation in brainstem trigeminal neurons. J Neurophysiol 1998;79:964-982.

6. Dodick DW, Campbell JK. Cluster headache: diagnosis, management, and treatment. In: Silberstein SD, Lipton RB, Dalessio D, eds. Wolff's Headache and Other Head Pain. 7th ed. New York: Oxford University Press, 2001:283-309.

7. Goadsby PJ, Edvinsson L. Human in vivo evidence for trigeminovascular activation in cluster headache. Brain 1994;117(Pt 3):427-434. 
TABLE 1: Occurrence of brush allodynia in the different patient groups

\begin{tabular}{|c|c|c|c|c|}
\hline Allodynia & $\begin{array}{c}\text { Episodic CH } \\
\text { (in acute } \\
\text { attack) }\end{array}$ & $\begin{array}{c}\text { Episodic CH (not in acute } \\
\text { attack) }\end{array}$ & Chronic CH (not in attack) & Total \\
\hline Yes & 1 & 1 & 2 & 4 \\
\hline No & 1 & 4 & 1 & 6 \\
\hline Total & 2 & 5 & 3 & 10 \\
\hline
\end{tabular}

Authors' final version prior to publication in Headache 44(10):1010-1012, November 2004.

Copyright $(\mathrm{C} 2004$ by Blackwell Publishing, Inc. 
TABLE 2: Disease duration in patients with and without brush allodynia

\begin{tabular}{|c|c|c|c|}
\hline \multirow{2}{*}{ Allodynia } & \multicolumn{3}{|c|}{ Disease Duration (years) } \\
\cline { 2 - 4 } & Minimum & Median & Maximum \\
\hline Yes & 1.5 & 22 & 38 \\
\hline No & 6 & 12 & 24 \\
\hline
\end{tabular}

